\title{
Seed Quality and Vigor of Germination of Moringa oleífera Lam. in Saline Stress
}

\author{
Jackson Silva Nóbrega ${ }^{1 *}$ \\ https://orcid.org/0000-0002-9538-163X
}

Kilson Pinheiro Lopes ${ }^{2}$

https://orcid.org/0000-0003-1577-5901

\section{Camile Dutra Lourenço Gomes ${ }^{2}$ \\ https://orcid.org/0000-0003-2718-6178}

\author{
Jolinda Mercia de Sá \\ https://orcid.org/0000-0003-4953-2641 \\ Odair Honorato de Oliveira ${ }^{3}$ \\ https://orcid.org/0000-0001-5462-241X
}

\author{
Francisco Jean da Silva Paiva ${ }^{4}$ \\ https://orcid.org/0000-0001-7603-4782
}

${ }^{1}$ Federal University of Paraíba, Department of Plant Science and Environmental Sciences, Areia, Paraíba, Brazil; ${ }^{2}$ Federal University of Campina Grande, Center for Science and Agri-Food Technology, Pombal, Paraíba, Brazil; ${ }^{3}$ Federal University of Grande Dourados, Department of Phytotechnics, Dourados, Mato Grosso do Sul, Brazil; ${ }^{4}$ Federal University of Campina Grande, Department of Agricultural Engineering, Campina Grande, Paraíba, Brazil.

Editor-in-Chief: Alexandre Rasi Aoki

Associate Editor: Adriel Ferreira da Fonseca

Received: 2021.02.25; Accepted: 2021.07.21.

*Correspondence: jacksonnobrega@hotmail.com; Tel.: +55-83-999749357 (J.S.N.).

\section{HIGHLIGHTS}

- M. oleífera is tolerant to the effect of salinity.

- Seed vigor is reduced by salinity.

- Germination of moringa seeds lasts 86 hours.

\begin{abstract}
Moringa oleifera Lam., is a tree species that has several purposes of use, standing out in the recovery of degraded areas and the use of seeds as biodsorbents in water clarification. However, ony a little is known about the behavior of seed germination under saline conditions, common in soils and water in the Brazilian Northeast. Thus, the objective was to evaluate the increment of water during the soaking and seed germination of $M$. oleiffera that were submitted to different electrical conductivity of the irrigation water. The work was developed following a completely randomized design, with stress simulation employing saline solutions at the concentrations of $0.0 ; 3.0 ; 6.0$ and $9.0 \mathrm{dS} \mathrm{m}^{-1}$. To determine the soaking curve, the water increment of the soaked seeds in the different saline solutions was monitored at regular intervals with four replications per treatment. To characterize the physiological quality of the seeds, the percentage, first count, speed index, average time and average germination speed were evaluated. The $M$. oleifera is tolerant to the effect of salinity during the germination phase, however seed vigor is reduced as a function of increased salinity. Soaking the seeds makes begin the phase II of the germination process around 10 hours and extends for up to 50 hours, when phase III begins, they absorb approximately $0.2 \mathrm{~g}$ of water and require 86 hours for germination. Salinity reduces the absorption and increase of water in the seeds.
\end{abstract}

Keywords: Forest species; Seed physiology; salinity. 


\section{INTRODUCTION}

The Moringa oleifera Lam., is a species of Indian origin that has satisfactorily adapted to the edaphoclimatic conditions of the semiarid region of northeastern Brazil [1]. It presents a great purpose of uses, such as the use for food and feed, recovery of degraded areas, in the cosmetics and pharmaceuticals industry [2]. Its leaves, flowers and fruits have a high concentration of proteins, vitamins and minerals and its seeds have a high amount of high quality oil [3].

Despite having a great ability to adapt to the climatic conditions of the Northeast region of Brazil, the high content of salts contained in the soil and waters used in irrigation can compromise the crop development. The excess of salts is responsible for promoting major biochemical and physiological disturbances resulting from reduced water availability and phytotoxicity promoted by ions, especially the $\mathrm{Na}^{+}$and $\mathrm{Cl}^{-}$[4-5].

Several factors are capable of affecting seed germination and vigor, among them abiotic stresses such as saline can compromise germination potential and initial plant establishment. Among the phases of plant development, salt stress causes greater damage during germination, emergence and initial seedling growth [6-7].

Among the effects promoted by salinity on seed quality is mainly due to the increased osmotic potential of the substrate, preventing the absorption of water by the seed [8-9]. In addition to the aggressiveness of specific ions that result in seed deterioration, causing toxicity to the embryonic axis [10].

In this context, this study aimed to evaluate the evaluate the increase of water during the imbibition and germination of $M$. oleiffera seeds that were submitted to different electrical conductivity of the irrigation water.

\section{MATERIAL AND METHODS}

The research was carried out at the Seeds and Seedling Analysis Laboratory of the Center for Agrifood Science and Technology of the Federal University of Campina Grande (CCTA / UFCG), Campus Pombal, Paraíba, Brazil ( $06^{\circ} 46^{\prime} 13^{\prime \prime} S, 37^{\circ} 48^{\prime} 06^{\prime \prime} \mathrm{W}$ and $242 \mathrm{~m}$ of altitude). According to the Köppen classification, the predominant climate is Bsh (semi-arid), hot and dry, with precipitation of approximately $700 \mathrm{~mm}^{2} \mathrm{ear}^{-1}[11]$.

$M$. oleifera seeds harvested from 10 healthy mother plants were used and sent to the laboratory, where they were submitted to beneficiation with the removal of wings that involves the seed. Seeking uniformity of plant material, seeds were selected for color, size and physical purity, and the most uniform were separated to compose the treatments.

The experiment was conducted using a completely randomized design (CRD), using four treatments related to different electrical conductivity of water. $\left(E C w=0.0 ; 3.0 ; 6.0\right.$ e $\left.9.0 \mathrm{dS} \mathrm{m}^{-1}\right)$, with four repetitions of 50 seeds. For the preparation of saline solutions, the following sodium chloride salts were used. $(\mathrm{NaCl})$, calcium chloride $\left(\mathrm{CaCl}_{2}\right)$, magnesium chloride $\left(\mathrm{MgCl}_{2}\right)$ in the ratio of $7: 2: 1$, and these were the most commonly found in Northeastern Brazil [12].

To characterize the water gain by seeds soaked in solutions with different saline concentrations, the soaking curve was performed. Four repetitions of 50 seeds were used and sown on two sheets of paper.: Germitest ${ }^{\circledR}$ previously moistened with saline solutions in a volume equal to 2.5 times the dry paper weight and packed in a germination chamber of the type: B.O.D. (Biochemical Oxygen Demand) at $25{ }^{\circ} \mathrm{C}$ and photoperiod of 8 hours. Initially, the dry mass of the seeds was obtained on a precision analytical balance and after the installation of the experiment, the weighings were performed every two hours, from the introduction of the seeds in the germination chamber for 24 hours until the initial stabilization of their water gain, then weighing every four hours until the resorption of water absorption and beginning of radicle protrusion.

To evaluate the effect of different electrical conductivities of water on the physiological quality of seeds, a standard germination test was performed, distributed on two sheets of paper: Germitest ${ }^{\circ}$ moistened with saline solutions in an amount equivalent to 2.5 times the weight of dry paper and stored in a germination chamber of the kind: B.O.D. (Biochemical Oxygen Demand) at 25을 and photoperiod of 8 hours, with the evaluations extending until the 15th day after sowing, and they are considered germinated those that emitted the radicle protrusion and the leaf beginnings [13].

In conjunction with the germination test, the first count was performed, evaluating the number of germinated seeds on the 4th after sowing, with the results expressed as a percentage. The germination speed index was obtained from daily counts of the number of germinated seeds and calculated according to Maguire [14]. The average germination time was established by counting germinated seeds and calculated by the formula established by Labouriau [15]. The average germination speed was determined from the number of seeds germinated each day and calculated as proposed by Labouriau and Valadares [16]. 
The data obtained for seed germination and vigor were submitted to analysis of variance by the $F$ test and regression analysis using the statistical program. Sisvar® [17].

\section{RESULTS}

Figures 1, 2, 3 and 4 represent the changes in the weight $(\mathrm{g})$ and amount of water $(\mathrm{g})$ curves that the seed absorbs at different salinity until germination. When $M$. oleifera seeds were soaked in pure water (Figure 1) it required 86 hours of soaking for root emission and total absorption of approximately 0.20 grams of water by the seed for germination to occur. However, when soaked in the waters of electrical conductivity of 3.0; 6.0 and $9.0 \mathrm{dS} \mathrm{m}^{-1}$ (Figure 2, 3 and 4, respectively), the necessary soak time for root protrusion was 86, 126 and 134 hours, respectively, and a reduction of up to 0.06 grams in the amount of water absorbed by the seed for germination to occur.

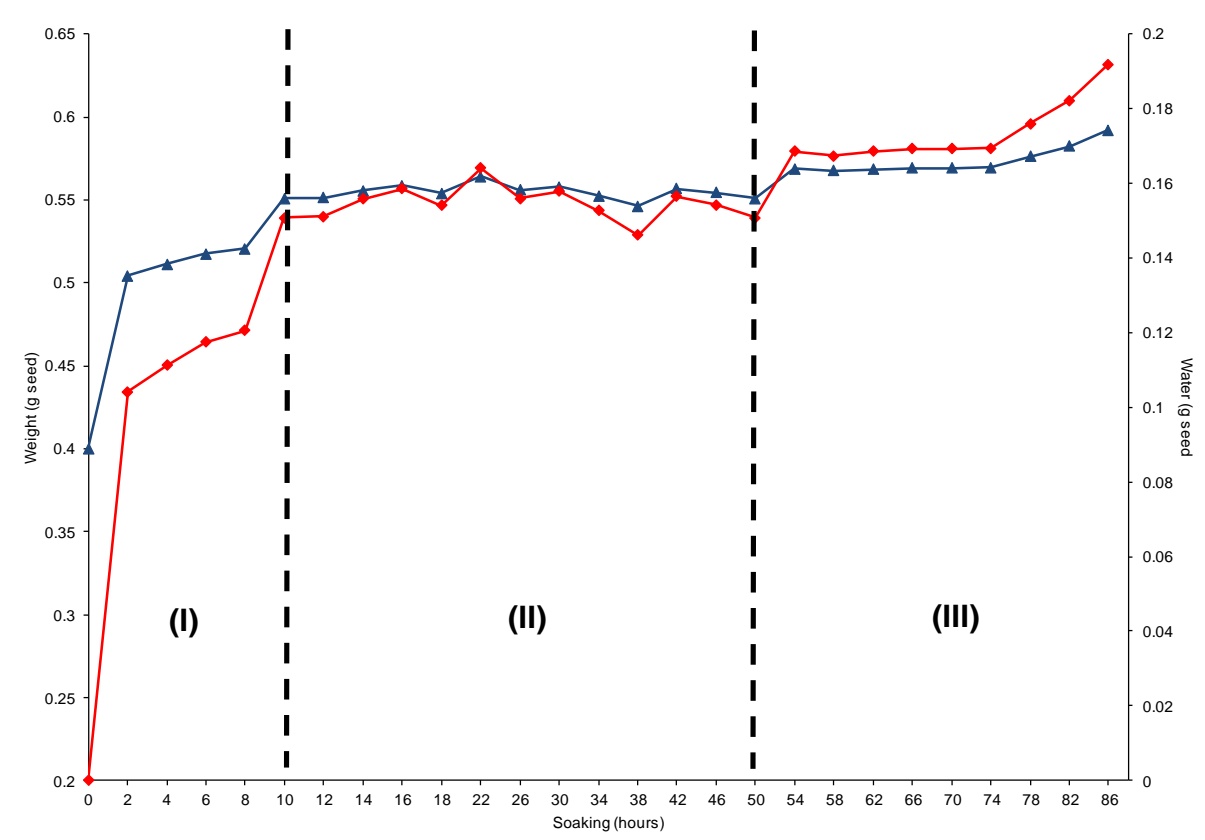

Figure 1. Amount of water soaked $[g$ seed $(\Delta)]$ and seed mass $[g(\triangleleft)]$ of Moringa oleífera Lam.

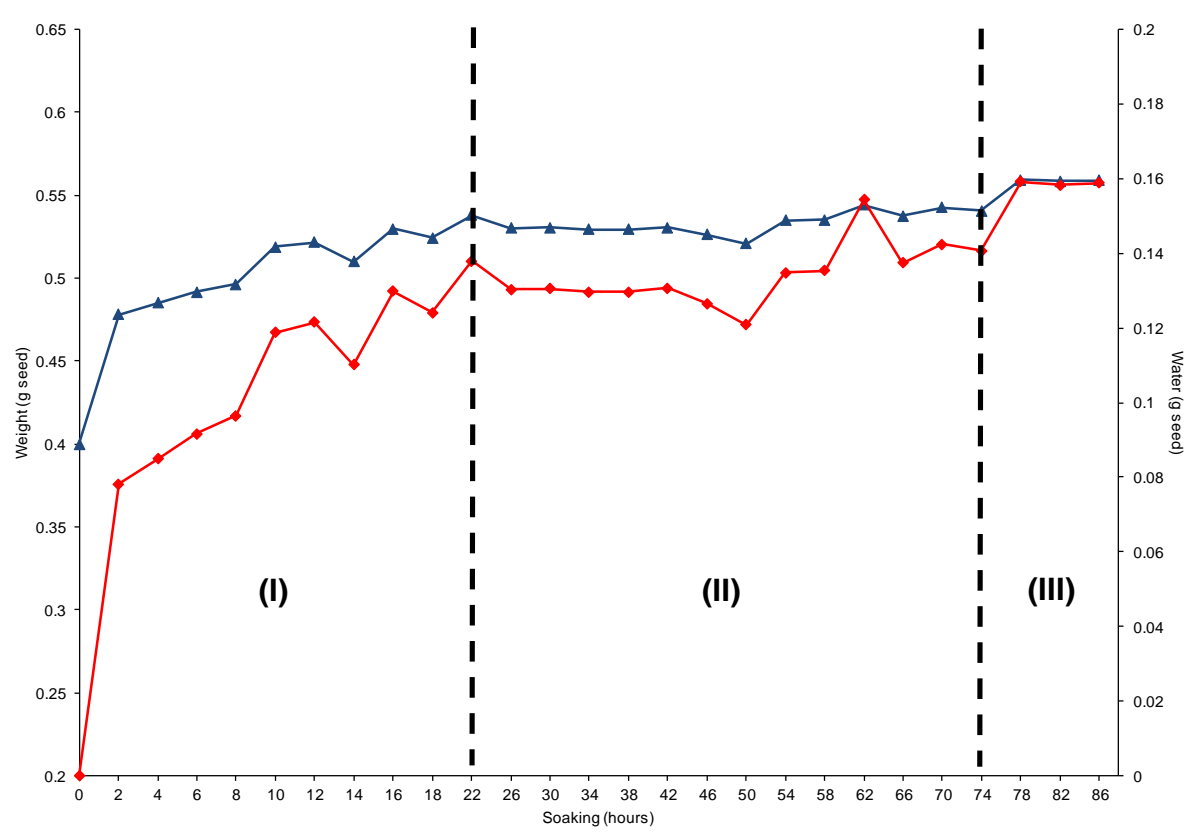

Figure 2. Amount of water soaked $[g$ seed $(\Delta)]$ and seed mass $[g(\diamond)]$ of Moringa oleifera Lam on the electrical conductivity of $3.0 \mathrm{dS} \mathrm{m}^{-1}$. 


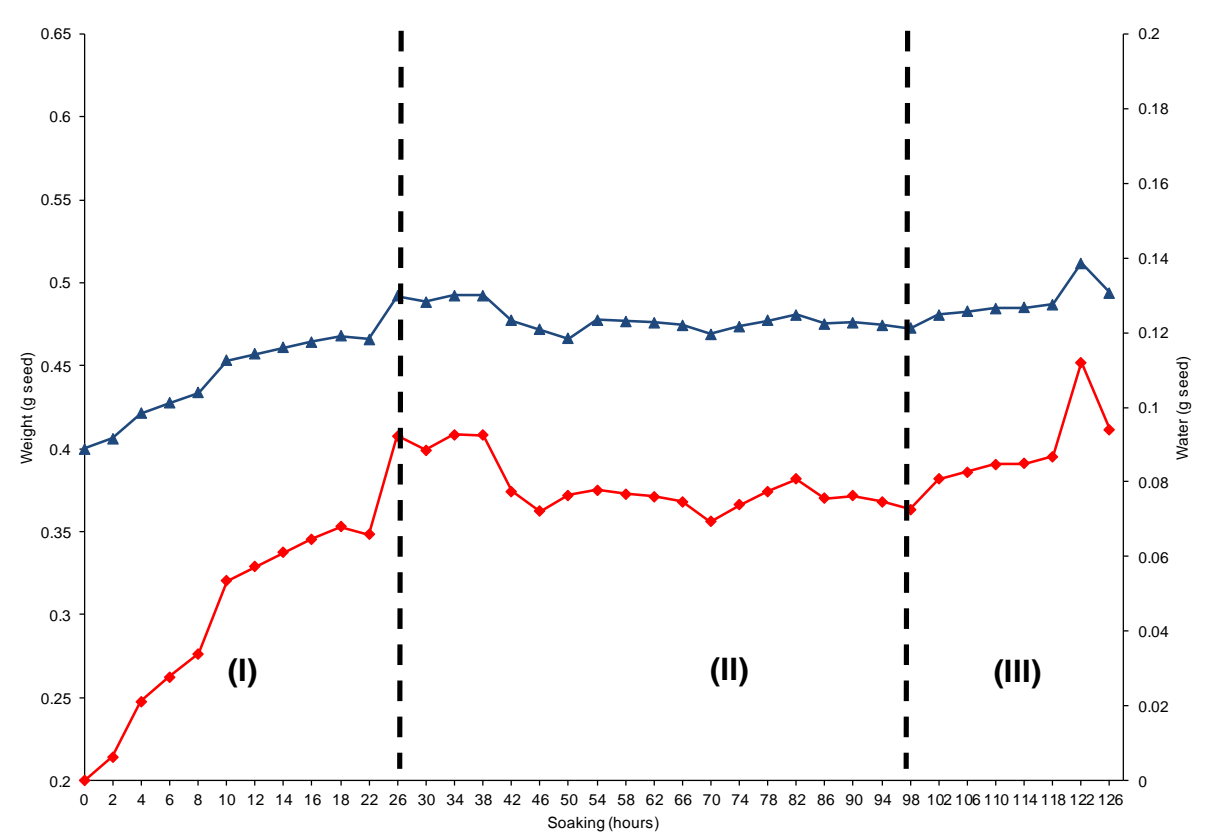

Figure 3. Amount of water soaked [g seed $(\Delta)$ ] and seed mass [g ( $\bullet)$ ] of Moringa oleifera Lam on the electrical conductivity of $6.0 \mathrm{dS} \mathrm{m}^{-1}$.

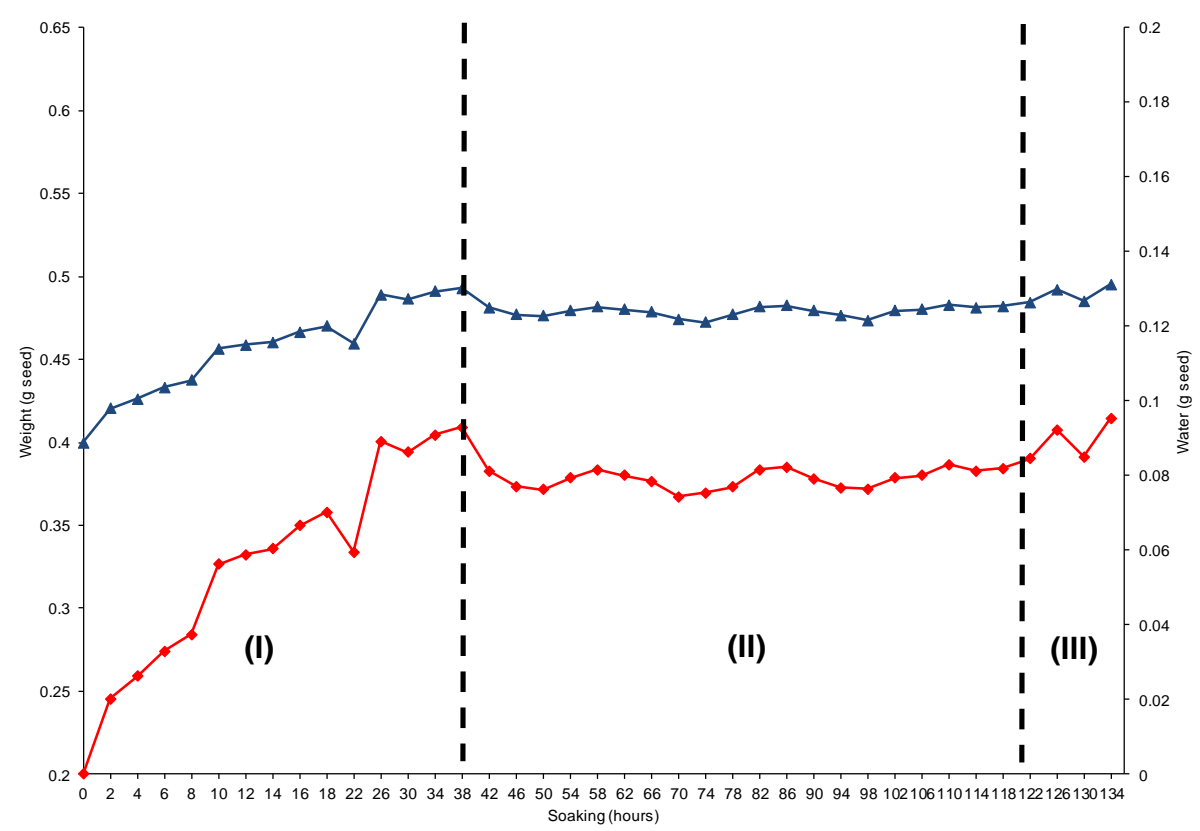

Figure 4. Amount of water soaked [g seed $(\boldsymbol{\Delta})$ ]and seed mass $[g(\triangleleft)]$ of Moringa oleífera Lam on the electrical conductivity of $9.0 \mathrm{dS} \mathrm{m}^{-1}$.

M. oleifera seed water gain in the first phase of the germination process (Phase I) when soaked in pure water was rapid, lasting 10 hours after sowing (Figure 1) and reached 22, 26 and 38 hours, when soaked in the electrical conductivity of the water of 3.0, 6.0 and $9.0 \mathrm{dS} \mathrm{m}^{-1}$ (Figure 2, 3 and 4, respectively). In absolute terms, 0.15 and 0.14 grams of water per seed were absorbed in pure water and saline solution of $0.3 \mathrm{dS} \mathrm{m}$ ${ }^{1}$ and 0.09 grams of water per seed in the ECws of 0.6 and $0.9 \mathrm{dS} \mathrm{m}^{-1}$.

The second phase (Phase II) characterized by being stable, was completed in pure water after 50 hours of soaking and, in saline waters, with each addition of $3.0 \mathrm{dS} \mathrm{m}^{-1}$ in the soaking solution, a 24-hour increase in the time required for Phase II compliance was observed. 
In M. oleifera seeds the amount of water soaked in Phase II is greatly reduced $(\approx 0.01 \mathrm{~g}$ seed), however, from this point there is a resumption of water uptake by the seed and beginning of Phase III, and consequent resumption of embryonic axis growth.

The salinity had no effect on the germination potential of $M$. oleifera seeds, regardless of $E \mathrm{Cw}$, a final percentage of $100 \%$ germinated seeds was obtained. For the first germination count the values were better adjusted to the quadratic effect, with the highest percentage of germinated seeds $(88 \%)$ in the control treatment, followed by significant reductions of this variable with the increase in salinity, reaching losses of $95.4 \%$ over compare the values of the largest and smallest ECw (Figure 5A).
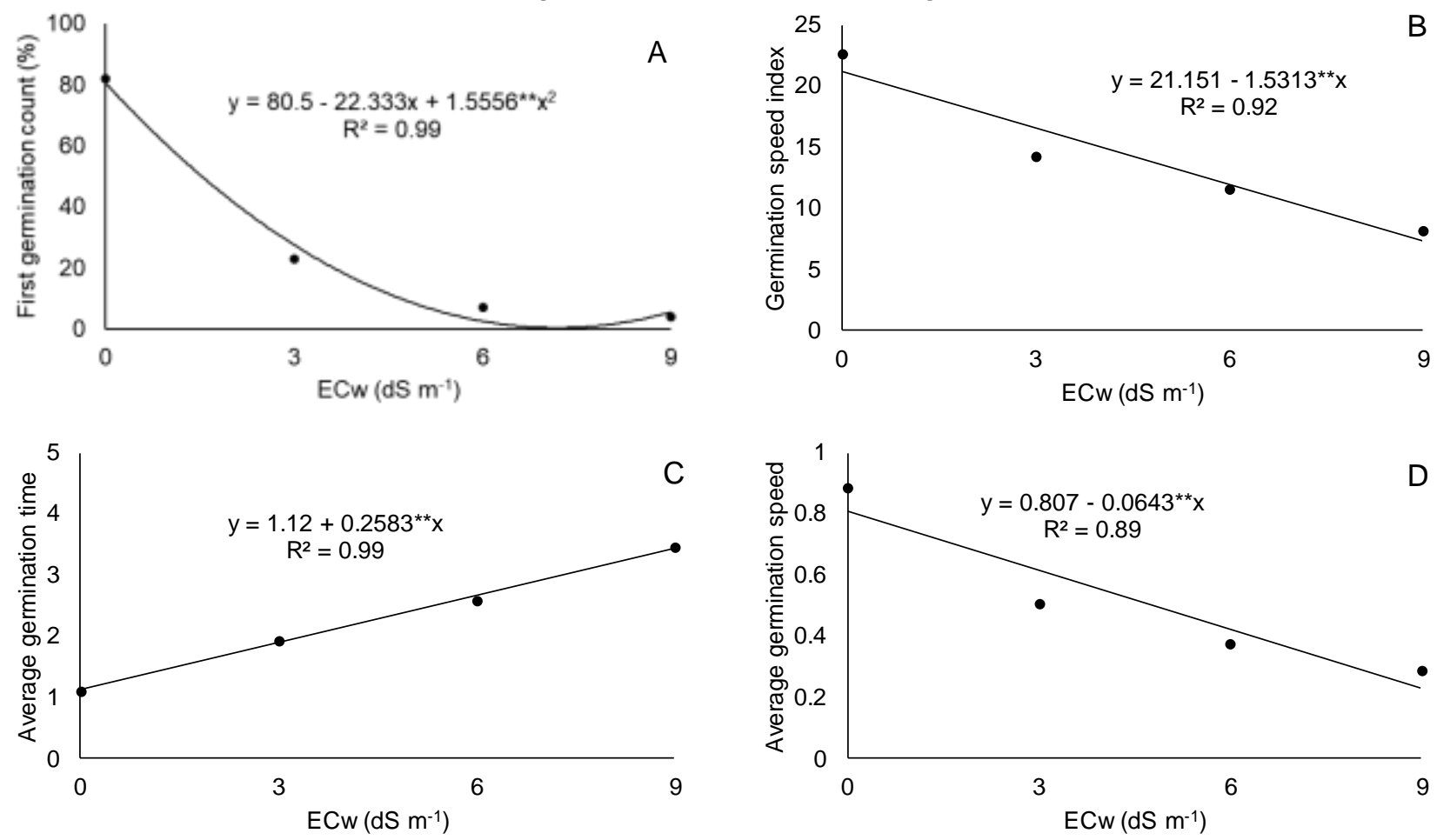

Figure 5. First germination count $(A)$ and germination speed index $(B)$, average germination time (C) and average germination speed (D) of seeds of Moringa oleifera Lam., submitted to different electrical conductivity of the irrigation water.

The rate of germination speed behaved in decreasing manner as the saline levels of the soaking solution were increased, where the highest value (22.7) was obtained in the control treatment, followed by decreases that reached $65.5 \%$ when comparing the values of the largest and smallest ECw (Figure 5B).

The average germination time of the seeds of $M$. oleifera was prolonged with increasing salt concentration in the soaking solution (Figure $5 \mathrm{C}$ ). On the other hand, the average germination velocity presented the opposite behavior, that is, it reduced the velocity with the increase of the soaking solution ECw, promoting $67.8 \%$ decreases when comparing the highest and lowest salinity values (Figure 5D).

\section{DISCUSSION}

M. oleifera germination under saline conditions presented the three-phase model proposed by Bewley and Black [18]. The water absorption process and weight gain during $M$. oleifera seed soaking is reduced by water absorption process and weight gain during seed soaking is reduced by the excess of soluble salts in the waters of different electrical conductivities, this happens due to these saline ions that promote reduction of water potential, and they induce lower water absorption capacity by seeds [19], which can affect the process of germination and seedling growth. Specifically, in Phase I, there is the beginning of seed hydration, and consequently of subcellular proteins, structural changes such as membrane and DNA repair, beyond the beginning and increased breathing, that happens within the first 10 hours.

During Phase II, it is called stationary and is characterized by a drastic reduction in the rate of hydration and intensification of respiration [10], with low water absorption by the seeds of $M$ oleifera, occurring an increase in absorption and respiratory activity in Phase III, culminating in the protrusion of the root, which occurs when the expansive force of the embryo exceeds the mechanical retention system of the endosperm and the integument ruptures [20-21]. 
The representative scheme of the metabolic events that occur during the soaking of $M$. oleifera seeds, and its factor is the amount of water absorbed which is presented in the figure 6 . It is possible to highlight the role of water in the metabolic activity of the seed, from tissue hydration, protein hydrolysis to tegument rupture and, consequently, root protrusion.

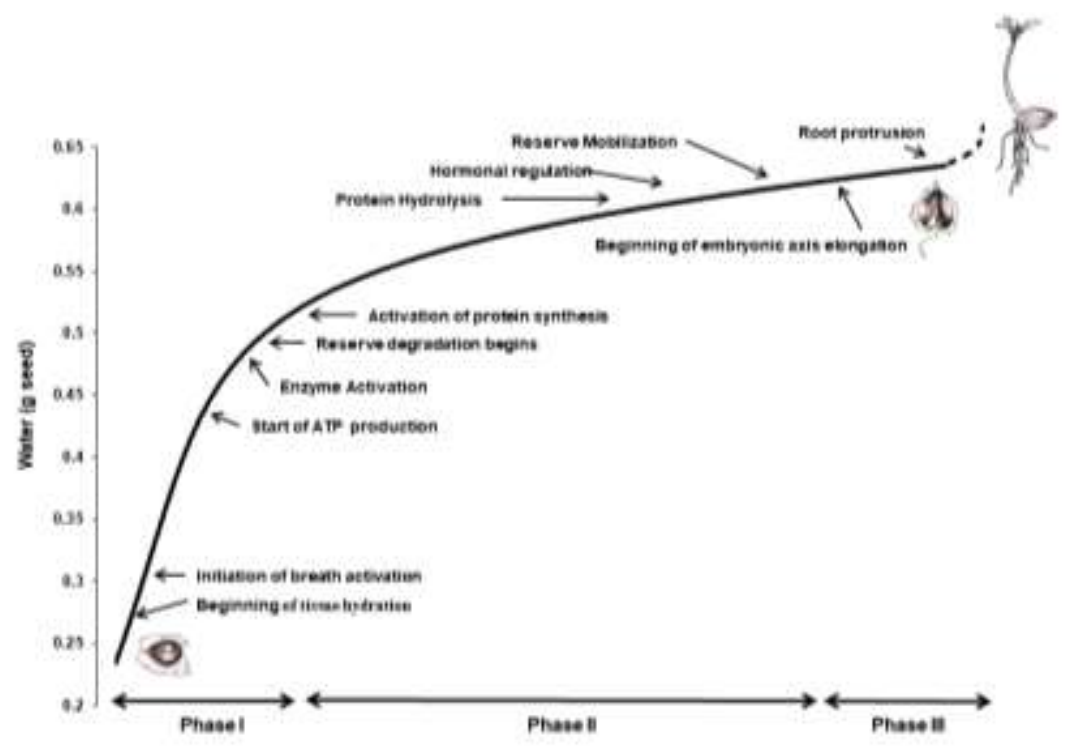

Figure 6. The representative scheme of metabolic events during seed soaking of Moringa oleífera Lam. Source: image of the authors.

Studies such as this, which determine the water imbibition curve by the seeds, and these studies are important to assist the integument impermeability studies, to determine treatments with plant regulators, osmotic conditioning, seed prehydration and seed behavior evaluation under abiotic stress conditions.

The salinity had no direct effect on the $M$. oleifera seed germination, such behavior may be a physiological response of the species when subjected to such stress conditions, allowing, even under adverse conditions, seedling germination and emergence. Possibly, the species has high rusticity, allowing a greater survival capacity in saline environments due to its genetic variability and osmotic adjustment to high salt concentration [22].

In this sense, Nouman and coauthors [23] evaluating the response of the formation of seedlings of $M$. oleiffera under saline conditions, it was found that they withstood well until the salinity of $8.0 \mathrm{dS} \mathrm{m}^{-1}$ presenting a slight reduction in biomass and some changes in physiological parameters related to photosynthesis and oxidative proteins.

However, the seed vigor presented by the first count, speed index, average time and average germination speed is reduced with increasing amount of salts contained in water. The high salt content tends to slow or reduce seed germination and vigor by impairing water absorption kinetics and increasing the absorption of toxic ions during soaking [24]. The increasing osmotic potential and reducing substrate water potential reduces the availability of water to the seed and, associated with this, is the fact that the high concentration of ions, especially $\mathrm{Na}^{+}$and $\mathrm{Cl}^{-}$, can be toxic to seedlings, causing reductions in their vigor, abnormalities or their death [25].

The occurrence of these decreases in seed vigor represented by the first germination count and germination speed index is reported by other authors, as Possas [26] when he metioned the Jatropha curcas L., where it was found that the salinity of $8.1 \mathrm{dS} \mathrm{m}^{-1}$ which reduced First germination count by $45 \%$ and above $0.6 \mathrm{dS} \mathrm{m}^{-1}$ losses in seed germination speed occur. In Mimosa ophthalmocentra Mart. ex Benth. the salinity also reduces the speed of germination, but the species presents satisfactory germination up to $20 \mathrm{dS} \mathrm{m}^{-1}$ [27].

This result is due to the high content of salts dissolved in the substrate, promoting the increase of osmotic potential and, consequently, it decreases the water availability for the seed. Thus, the rate of water absorption by the seed decreases, resulting in increased time and minimum water content for the embryonic axis growth to resume and seed germination process [28]. This fact was observed by Dutra [19] in Peltophorum dubium Sprengel Taubert, Enterolobium contortisiliquum (Vell.) Morong. e Triplaris americana L. 


\section{CONCLUSIONS}

The $M$. oleifera is tolerant to the effect of salinity during the germination phase, but seed vigor is affected by the increase of salt concentration in irrigation water.

The seeds of $M$. oleifera start the phase II of the germination process around 10 hours of imbibition and extend for up to 50 hours when phase III begins, they absorb approximately $0.2 \mathrm{~g}$ of water and require 86 hours for germination; The absorption and increment of water in the seeds is reduced by the increase of salinity.

Acknowledgments: To the Tutorial Education Program in Agronomy (PET-Agronomy) of the Federal University of Campina Grande for helping in the development of the research.

Conflicts of Interest: None.

\section{REFERENCES}

1. Valdivié-Navarro M, Martínez-Aguilar $Y$, Mesa-Freitas $O$, Botello-León A, Hurtado CB, Velázquez-Martí B. Review of Moringa oleifera as forage meal (leaves plus stems) intended for the feeding of non-ruminant animals. Ani. Feed Sci. Tech. 2020 Feb; 260: 114338.

2. Raman JK, Alves CM, Gnansounou, E. A review on moringa tree and vetiver grass - Potential biorefinery feedstocks. Bior. Tech. 2018 Feb; 249: 1044-51.

3. Sagona WCJ, Chirwa PW, Sajidu, SM. The miracle mix of Moringa: Status of Moringa research and development in Malawi. South Afric. J. Bot. 2019 March; 129: 138-45.

4. Acosta-Motos JR, Ortuño MF, Bernal-Vicente A, Diaz-Vivancos P, Sanches-Blanco MJ, Hernandez JA. Plant responses to salt stress: adaptive mechanisms. Agronomy. 2017 Feb; 7: 1-38.

5. Sarabi B, Fresneau C, Ghaderi N, Bolandnazar S, Streb P, Badeck FW, et al. Stomatal and non-stomatal limitations are responsible in down-regulation of photosynthesis in melon plants grown under the saline condition: Application

6. of carbon isotope discrimination as a reliable proxy. Plant Phys. Bioch. 2019 Aug; 141: 1-19.

7. Munns R, Tester M. Mechanisms of salinity tolerance. Annual Rev. Plant Biol. 2008 June; 59: 651-81.

8. Shrivastava P, Kumar R. Soil Salinity: A serious environmental issue and Plant growth promoting bacteria as one of the tools for its alleviationr. Saudi J. Biol. Sci. 2015 March; 22: 123-31.

9. Kataria S, Baghel L, Guruprasad KN. Pre-treatment of seeds with static magnetic field improves germination and early growth characteristics under salt stress in maize and soybean. Biocat. Agric. Biotec. 2017 Apr; 10: 83-90.

10.Jovičić D, Popovič BM, Jeromela AM, Nikolič Z, Ignjatov M, Miloševič D. The interaction between salinity stress and seed ageing during germination of Brassica Napus seeds. Seed Sci. Tech. 2019 Apr; 47: 47-52.

11.Zang N, Zang HJ, Sun QQ, Cao YY, Li X, Zhao B, et al. Proteomic analysis reveals a role of melatonin in promoting cucumber seed germination under high salinity by regulating energy production. Sci. Rep. 2017 Mar;7:1-15.

12.Alvarez, CA, Stape JL, Sentelhas PC, Gonçalves JLM, Sparover G. Köppen's climate classification map for Brazil. Meteorolog. Zeitsch. 2013 Jan: 22: 711-28.

13.Medeiros JF. Qualidade da água de irrigação e evolução da salinidade nas propriedades assistidas pelo "GAT" nos Estados do RN, PB e CE. 1992. Dissertação do Programa de Pós-Graduação em Engenharia Agrícola da Universidade Federal da Paraíba. Campina Grande - PB, 1992. 173p.

14.Brasil. Regras para análise de sementes. 1 ed. Mapa/ACS, Brasília, 2009.

15.Maguire JD. Speed of germination-aid in selection and evaluation for seedling emergence vigor. Crop Sci. 1962 Mar;2:176-77.

16.Labouriau, LG. A germinação das sementes. Washington: Secretaria da OEA. (1983).

17.Labouriau LG, Valadares MEB. On the germination of seeds Calotropis procera (Ait.) Ait.f. Anais Acad. Bras. Cie. 1976;48:263-84.

18.Ferreira DF. Sisvar: a computer analysis system to fixed effects split plot type designs. Rev. Bras. Biom. 2019 Dec;37:529-35.

19.Bewley JD, Black M. Seeds: Physiological of developmente and germination. 1th ed. Plenum press, New York. 1994.

20.Dutra TR, Massad MD, Moreira PR, Ribeiro ESM. Efeito da salinidade na germinação e crescimento inicial de plântulas de três espécies arbóreas florestais. Pes. Flor. Bras. 2017 Sep;37:323-30.

21. Moreno C, Seal CE, Papenbrock J. Seed priming improves germination in saline conditions for Chenopodium quinoa and Amaranthus caudatus. J. Agron. Crop Sci. 2017 Oct;204:40-8.

22.Lechowska K, Kubala S, Wojtyla $Ł$, Nowaczyk G, Quinet M, Lutts S, et al. New insight on water status in germinating Brassica napus seeds in relation to priming-improved germination. Int. J. Mol. Sci. 2019 Jan; 20: 540.

23.Dolferus R. To grow or not to grow: A stressful decision for plants. Plant Sci. 2014 Dec;229:247-61. 
24. Nouman W, Siddiqui MT, Basra SMA, Khan RA, Gull T, Olson ME, et al. Response of Moringa oleífera to saline conditions. Int. J. Agric. Biol. 2012;14:757-62.

25.Belmehdi O, El Harsal A, Benmoussi M, Laghmouchi Y, Skali SN, Abrini J. Effect of light, temperature, salt stress and $\mathrm{pH}$ on seed germination of medicinal plant Origanum elongatum (Bonnet) Emb. \& Maire. Biocat. Agric. Biotec. 2018 Oct; $16: 126-31$.

26. Gadelha CG, Miranda RS, Alencar NLM, Costa JH, Prisco JT, Gomes Filho E. Exogenous nitric oxide improves salt tolerance during establishment of Jatropha curcas seedlings by ameliorating oxidative damage and toxic ion accumulation. J. Plant Phys. 2017 May;212:69-79.

27.Possas JMC, Nascimento R, Maia Filho FCF, Nascimento DAM, Alencar AEV. Efeito da salinidade na germinação de pinhão manso. Rev. Ver. Agroec. Desenv. Sust. 2014 Dec;9:184-88.

28. Nogueira NW, Torres SB, Freitas RMO, Santos PC, Sá FVS, Leite MS. Salt stress and temperatures on the germination and initial growth of 'jurema-de-embira' (Mimosa ophthalmocentra) seedlings. Rev. Bras. Eng. Agríc. Amb. 2018;22:273-76.

29.Wu GQ, Jiao Q, Shui QZ. Effect of salinity on seed germination, seedling growth, and inorganic and organic solutes accumulation in sunflower (Helianthus annuus L.). Plant. Soil. Env. 2015; 61: 220-26.

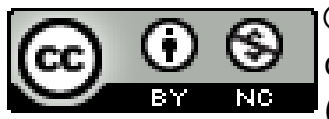

2021 by the authors. Submitted for possible open access publication under the terms and conditions of the Creative Commons Attribution (CC BY NC) license (https://creativecommons.org/licenses/by-nc/4.0/). 